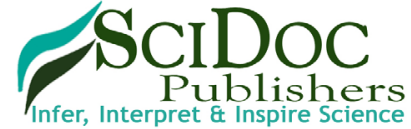

International Journal of Food Science, Nutrition and Dietetics (IJFS)

ISSN 2326-3350

\title{
Evaluation of Microbial Contamination of vended Frozen Fish in Ado Ekiti Locality
}

Research Article

Peter Taye Olagbemide ${ }^{1}$, Fred Coolborn Akharaiyi ${ }^{*}$

${ }^{1}$ Afe babalola University, P.M.B. 5454, Ado Ekiti, Ekiti State, Nigeria.

${ }^{2}$ Edo University Iyamho, KM 7 Auchi-Abuja Road, Iyamho-Uzairue, Edo State, Nigeria.

\section{Abstract}

The basic nutrient of protein in fish that is so important in man's diet also attracted microorganisms for their growth and multiplication. Meanwhile, the association of microorganisms in fishes depend on environment of culture and their proliferations due to inadequate storage facilities. This study examined microbial contamination of some frozen fishes (Atlantic Mackerel (Scomber scombrus), White hake (Urophycis tenuis), Atlantic herring (Clupae harengus) and Tracburus trachurus (Atlantic horse mackerel) vended in Ado Ekiti metropolis. On the fish samples, total heterotrophic count (THC) of between $3.5 \times 10^{4}-5.6 \times 10^{4}$ colony forming unit per gram (Cfu/g), Coliform count in total (CCT) of $2.4 \times 10^{4}-5.1 \times 10^{4} \mathrm{Cfu} / \mathrm{g}$, Salmonella/Shigella counts in total (SSCT) of $1.3 \times 10^{4}-3.5 \times 10^{4} \mathrm{Cfu} / \mathrm{g}$, total Vibrio count (TVC) of $1.1 \times 10^{4}-2.3 \times 10^{4} \mathrm{Cfu} / \mathrm{g}$ and total fungal count (TFC) of $1.3 \times 10^{3}-2.3 \times 10^{3}$ Spore/g were analyzed by cultural methods. The microorganisms identified with their percentage occurrence are Bacillus cereus (11.54\%), Streptococcus faecium (13.46\%), Alcaligenes faecalis (5.77\%), Salmonella typhi (5.77\%), Micrococcus luteus (9.62\%), Vibrio cholerae (5.69\%), Aerococcus viridans (3.85\%), Pseudomonas aeruginosa (7.69\%), Xanthomonas fragariae (7.69\%), Staphylococcus aureus (11.54\%), Clostridium butyricum (7.68\%), Eschericbia coli (7.69\%), Aspergillus fumigatus (11.11\%), A. flavus (24.44\%), A. clavatus (8.89\%), A. fishcheri (6.69\%), A. terreus (8.89\%), Mucor mucedo (17.78\%), Penicillium digitatum (13.33\%) and A. parasiticus $(8.89 \%)$. The results obtained could serve as an awareness to consumers that microbial infection is possible from frozen fishes and also could serve as data for future reference in epidemiology or outbreak of disease from eating frozen fish.

Keywords: Ado Ekiti; Frozen Fish; Microbiological; Quality; Vended.

\section{Introduction}

Fish and their products are vital protein sources and have been reported that aquaculture made it possible for most of the fish that are consumed by humans [1]. Fish consumption by man has been for ages and till date served as important constituent in foods for number of some countries in the world. Fish are mainly consumed because of their high nutrient and the fact that when eaten digest easily. Fish inhabit different waters such as fresh water, salt water and warm water. Quite numbers of food borne illness caused in fish are majorly implicated by Staphylococcus species, Escherichia coli, Vibrio, Clostridium and Salmonella species [2]. They as well reported that inadequate processing of fish, non-compliance of good hygiene practice, dirty processing plants and inappropriate storage could result to fish contamination by microbes. When fish are not properly stored, they deteriorate quickly otherwise, they serves as means of protein and other required that helps in the maintenance of healthy body [3].

Pathogenic bacteria in fish are of two categories; those that are indigenous in fish and those not resident in fish. Bacteria pathogens such as Salmonella, Clostridium, Staphylococcus species, Escherichia coli and Listeria monocytogenes are examples of the nonindigenous and they contaminate fish habitats. The indigenous bacteria such as Aeromonas and Vibrio species are the naturally occurring pathogens found in the environment where fish inhabits [4]. Bacteria pathogens like Vibrio, Alcaligenes Pseudomonas, Flavobacterium and Moraxalla species can grow in fish, survive freezing temperature and are able to resume spoilage of fish when thawed [5]. Clostridium botulinum can in freezing temperature and is able produce toxins in fish when temperature is lowered to $3^{\circ} \mathrm{C}[5]$. Fish are contaminated before freezing as result of poor

*Corresponding Author:

Fred Coolborn Akharaiyi,

Edo University Iyamho, KM 7 Auchi-Abuja Road, Iyamho-Uzairue, Edo State, Nigeria.

Tel: +234 8066982772

E-mail: akharaiyi.fred@edouniversity.edu.ng

Received: September 30, 2020

Accepted: October 08, 2020

Published: April 03, 2021

Citation: Peter Taye Olagbemide, Fred Coolborn Akharaiyi. Evaluation of Microbial Contamination of vended Frozen Fish in Ado Ekiti Locality. Int J Food Sci Nutr Diet. 2021;10(2):508 511. doi: http://dx.doi.org/10.19070/2326-3350-2100088

Copyright: Fred Coolborn Akharaiyi ${ }^{\circ} 2021$. This is an open-access article distributed under the terms of the Creative Commons Attribution License, which permits unrestricted use, distribution and reproduction in any medium, provided the original author and source are credited. 
design of plants and the methods of fish catching [6]. Due to the many ways fish can be contaminated, this study was aimed to identify the microorganisms associated with frozen fish vended in some markets in Ado Ekiti of Nigeria.

\section{Materials and Methods}

\section{Collection of Samples}

Four each of different fish species namely Atlantic Mackerel (Scomber scombrus), Atlantic herring (Clipea harengus), White hake (Urophycis tenuis) and Atlantic horse mackerel (Trachurus trachurus). The fish samples were randomly purchased at different period of morning and evening from retailers in two different markets within Ado-Ekiti Metropolis. The purchased fish samples were wrapped in sterile polythene bag and contained in a cooler stocked with ice cubes. The fish were taken to the laboratory where they were microbiologically analyzed under aseptic condition.

\section{Sample Preparation}

The method of Obi and Krakowiaka [7] was used where $10 \mathrm{~g}$ each of head, middle and tail of test fish were cut ground with $10 \mathrm{ml}$ of sterile water in sterile mortar and pestle. From the mixture, $1 \mathrm{ml}$ was serially diluted to $10-10$.

\section{Inoculation, enumeration and identification of isolates}

One millilitre of the serially diluted fish samples obtained with sterile pipette were spread plated on culture media for enumeration and preliminary identification. Plates for bacteria cultivation were incubated for $24 \mathrm{~h}$ at $37^{\circ} \mathrm{C}$ and the plates for fungi cultivation were incubated for $72 \mathrm{~h}$ at $28 \pm 2{ }^{\circ} \mathrm{C}$. The samples were cultured on different medium. General enumeration of bacteria was with plate count agar, for Salmonella and Shigella species Salnomella/Shigella agar was used, for the growth of Staphylococcus aureus, Mannitol Salt agar was used, for the growth of Enterobacteriaceae, Violet Red Bile Glucose Agar was used, for the growth of Vibrio species, Thiosulfate Citrate Bile Salt Sucrose Agar was used, for the growth of Escherichia coli, Eosin Methylene Blue Agar was used and for any other bacteria that might be present in the samples, Nutrient agar was used. Resultant colonies were enumerated and those identifiable as discrete were purified by streaking on freshly prepared Nutrient Agar.

The isolates were Gram-stained to observe for cell morphology and uniformity. Pure isolates were identified by the criteria of Cheesbrough [8], Holt et al. [9]. Fungal isolates were sub-cultured on Potato Dextrose Agar and identified based on their morphological and cultural characteristics as described by the method of
Barmett et al. [10].

\section{Results and Discussion}

Total heterotrophic counts from the fish samples was more in $T$. trachurus with count of $5.6 \times 10^{4} \mathrm{CFU} / \mathrm{g}$ in the sample purchased from Oba market. This was followed by $S$. scombrus purchased from Erinfun market with load of $5.4 \times 10^{4} \mathrm{Cfu} / \mathrm{g}$ count of $3.5 \times 10^{4} \mathrm{Cfu} / \mathrm{g}$ as the least count from $C$. harengus purchased from Oba market. Coliform bacteria were present in all the fish samples and the counts recorded was in the range of $2.4 \times 10^{4}$ to $5.1 \times 10^{4}$ $\mathrm{Cfu} / \mathrm{g}$. C. harengus purchased from Erinfun market was the most coliform bacteria populated sample with load of $5.1 \times 10^{4} \mathrm{CFU} / \mathrm{g}$. Following this was $S$. scombrus purchased from Erinfun market with load of $4.3 \times 10^{4} \mathrm{CFU} / \mathrm{g}$ and least count of $2.4 \times 10^{4} \mathrm{CFU} / \mathrm{g}$ from $U$. tenuis also purchased from Erinfun market. Count ranging from between $1.3 \times 10^{4}-3.5 \times 10^{4} \mathrm{CFU} / \mathrm{g}$ was recorded for total Salmonella/Shigella species. The count was highest in $U$. tenuis with load of $3.5 \times 10^{4} \mathrm{CFU} / \mathrm{g}$ in the sample purchased from Oba market. This was followed by a count of $2.8 \times 10^{4} \mathrm{CFU} / \mathrm{g}$ from $S$. scombrus purchased from Oba market and least count of $1.3 \times 104$ $\mathrm{CFU} / \mathrm{g}$ in C. harengus and T. trachurus purchased from Oba and Erinfun markets respectively. Total Vibrio count was more with load of $2.3 \times 10^{4} \mathrm{CFU} / \mathrm{g}$ in T. trachurus purchased from Oba market. Counts from other fish samples was between $1.1 \times 10^{4}-1.7 \times 10^{4}$ $\mathrm{Cfu} / \mathrm{g}$. However, no Vibrio count was recorded from S. scombrus and U. tenuis purchased from Oba market. Fungal counts was recorded in all the studied fish samples, with counts that ranged from $1.3 \times 10^{3}-2.3 \times 10^{3}$ Spore/g. S. scombrus purchased from Oba market had the highest fungal load of $2.3 \times 10^{3} \mathrm{Spore} / \mathrm{g}$, followed by $2.1 \times 10^{3}$ Spore/g recorded from $T$. trachurus purchased from Erinfun and least count of $1.3 \times 10^{3}$ Spore/g from U. tenuis purchased from Erinfun market (Table 1).

Fish is highly nutritious as known for its compositions and this has make man to source for it as a healthy diet. Meanwhile, the nutrient contents of fish highly encourages the growth of microorganisms. These microorganisms need the nutrients for growth and multiplication and not intended to cause harm for man. But the consumption of pathogen contaminated fish do result to infection and probably disease manifestation. Also contaminated fish with food spoilage microorganisms may set a foundation of loss to fish retailers if microbiological quality is not evaluated to sound warning on adequate preservation. Studying frozen fish's quality microbiologically, paves the way for update and adoption of quality storage methods.

Twelve bacteria species were isolated from the frozen fish samples. Isolated from the head of Clupea harengus include Bacillus cereus, Alcaligenes faecalis and Streptococcus faecium. From the middle re-

Table 1. Average microbial counts from fish samples in the surveyed markets.

\begin{tabular}{|c|c|c|c|c|c|c|}
\hline Fish samples & Market & THC (Cfu/g) & TCC (Cfu/g & TSSC (Cfu/g & TVC (Cfu/g) & TFC (Spore/g \\
\hline \multirow{2}{*}{ C.harengus } & Oba & $3.5 \times 10^{4}$ & $2.6 \times 10^{4}$ & $1.3 \times 10^{4}$ & $1.1 \times 10^{4}$ & $1.6 \times 10^{3}$ \\
\cline { 2 - 7 } & Erinfun & $4.2 \times 10^{4}$ & $5.1 \times 10^{4}$ & $3.4 \times 10^{4}$ & $1.3 \times 10^{4}$ & $1.4 \times 10^{3}$ \\
\hline \multirow{2}{*}{ S. scombrus } & Oba & $4.6 \times 10^{4}$ & $3.6 \times 10^{4}$ & $2.8 \times 10^{4}$ & - & $2.3 \times 10^{3}$ \\
\cline { 2 - 7 } & Erinfun & $5.4 \times 10^{4}$ & $4.3 \times 10^{4}$ & $1.7 \times 10^{4}$ & $1.5 \times 10^{4}$ & $2.0 \times 10^{3}$ \\
\hline \multirow{2}{*}{ T. trachurus } & Oba & $5.6 \times 10^{4}$ & $2.6 \times 10^{4}$ & $2.5 \times 10^{4}$ & $2.3 \times 10^{4}$ & $1.7 \times 10^{3}$ \\
\cline { 2 - 7 } & Erinfun & $4.3 \times 10^{4}$ & $3.7 \times 10^{4}$ & $1.3 \times 10^{4}$ & $1.4 \times 10^{4}$ & $2.1 \times 10^{3}$ \\
\hline \multirow{2}{*}{ U. tenuis } & Oba & $4.6 \times 10^{4}$ & $3.6 \times 10^{4}$ & $3.5 \times 10^{4}$ & & $1.6 \times 10^{3}$ \\
\cline { 2 - 7 } & Erinfun & $5.2 \times 10^{4}$ & $2.4 \times 10^{4}$ & $1.4 \times 10^{4}$ & $1.7 \times 10^{4}$ & $1.3 \times 10^{3}$ \\
\hline
\end{tabular}


gion were Streptococcus faecium, Salmonella typhi and Micrococcus luteus, while Streptococcus faecium and Vibrio cholerae were isolated from the tail region. Aerococcus viridans; Streptococcus faecium and Pseudomonas aeruginosa were respectively isolated from the head and middle regions of Scomber scombrus while Xanthomonas fragariae and Streptococcus faecium were isolated from the tail region. From the head of Trachurus trachurus, Xanthomonas fragariae and Staphylococcus aureus were isolated, from the middle region were Clostridium butyricum and Escherichia coli, while Streptococcus faecium and Aerococcus viridians were found at the tail region. From the head of Urophycis tenuis, Micrococcus luteus and Staphylococcus aureus were isolated, Vibrio cholerae, Escherichia coli and Alcaligenes faecalis were isolated from the middle region, while Xanthomonas fragariae $\backslash$ and Streptococcus faecium were isolated from the tail region.

The most frequently occurred bacteria specie was $M$. luteus with $16.3 \%$. This was followed by $S$. aureus with $11.1 \%$, while the least occurred bacteria was $V$. choleriae with $3.4 \%$ (Figure 1).

Spoilage of fish is dependent in quality based on the differences in the environment where they inhabit and species type. There were variations in microbiological quality among the studied fish in respect to microbial population in the surveyed markets. Total heterotrophic counts from the fish ranged between $3.5 \times 10^{4}$ $5.6 \times 10^{4}$ denoting that all the evaluated fish were microbiologically certified as been of good quality hence the counts was within the permissible level of international standard. ICMSE [11] accepted total count limit for coliform in frozen fish is $<100 \mathrm{MPN} / \mathrm{g}$. The total coliform counts from the fish samples as recorded in this study was between $2.4 \times 10^{4}-5.1 \times 10^{4}$. The encounter of coliform in the sampled fish is an indication of faecal contamination by either animals or humans of the water they were caught, though could also result from human handling and environment of storage. Salmonella and Vibrio bacteria species were encountered in majority of the evaluated fishes. By the standard of International Association of Microbiology Society, these species of bacteria should not the encountered in frozen fish. From this perspective, we cannot ascertain good quality of the fish samples despite the counts of other isolated pathogens that were within standard level. However, species of Salmonella and Vibrio have been reported in frozen fish by Adebayo-Tayo et al. [3], Popovic et al. [12], Sanjee and Karim [13]. Aspergillus flavus, the most dominant fungus among the isolated fungi have been reported in fish and salt water and have been identified as diseases causing fungi in animal and human as reported by Saleem et al. [14], Oranusi and Olarewaju, [15], Oranusi et al. [16].

The presence of Steptococcus faecium as the most dominant bacteria identified from the fish samples simplifies that the offshore water was contaminated with faecals of either man or animals. Though the infectious dose of this bacterium is unknown, the diseases it manifest such as urinary tract infection, wound infection, endocarditis and bacteremia may be zoonotic and communicable. Meanwhile, this bacterium has been found to be multiple drug resistance [17].

S. aureus been one of the pathogens isolated from the frozen fish, is a normal flora in man but not in fish, its presence in the samples could be attributed to contamination from personnel and environment [18]. Similarly, cross contamination via utensil have been well documented by Roche et al. [19], Harrington, [20], Berrange et al. [21].

Eight species of fungi were isolated from the frozen fish. From the head region of Clupea harengus, Aspergillus fumigatus and Aspergillus flavus were isolated, from the middle and tail regions, Aspergillus flavus and Aspergillus clavatus respectively. Isolated from Scomber scombrus are Aspergillus flavus from the head region, Mucor mucedo, Aspergillus fischeri and Aspergillus terreus from middle region, while Penicillium digitatum, Aspergillus terreus and Mucor mucedo were from the tail region. From the head region of Trachurus trachurus, Mucor mucedo, Aspergillus fumigatus and Aspergillus flavus were isolated. From the middle region were Aspergillus fumigatus and Aspergillus clavatus, while from the tail were Aspergillus flavus, Mucor mucedo and Aspergillus parasiticus. Urophycis tenuis was inhabited with Aspergillus flavus at the head region, Mucor mucedo and Penicillium digitatum from the middle region and; Aspergillus flavus and Aspergillus fumigatus from the tail region.

The result obtained from the fish denotes varied microbial contamination. From fungal contamination perspective, Aspergillus species were dominant in the fish samples from different regions. Meanwhile, $A$. terreus was the most frequently occurred among the isolated fungi with $18.6 \%$ occurrence, followed by $M$. mucedo $(15.2 \%)$ and $A$. fumigatus $(8.1 \%)$ as the least frequently occurred (Fig 2).

The microorganisms identified in this study seemed to be common among other species of frozen fishes in reports of researchers elsewhere. Research studies by some authors in Nigeria such as Okonko et al. [22], Chukwuka et al. [23], Akinmusire, [24], Adebayo-Tayo et al. [3] have isolated similar microorganisms from different frozen fishes in Nigeria. Edris et al. [25] from Egypt, Murad et al. [26] from Iran. Popovic et al. [12], have isolated Salmonella sp, E. coli, $S$. aureus and $V$. cholerae from fresh and frozen sea foods in Croatia.

It has been reported that microbial type and number in frozen fish is relatively on fish source, contamination from boat use in fishing, storage temperature, inconsistency in freezing process

Figure 1. Frequency of occurrences for bacteria isolated from frozen fish.

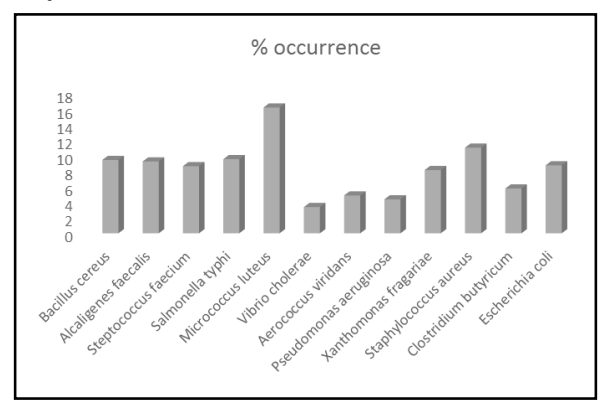


Figure 2. Frequency of occurrences for fungi isolated from frozen fish.

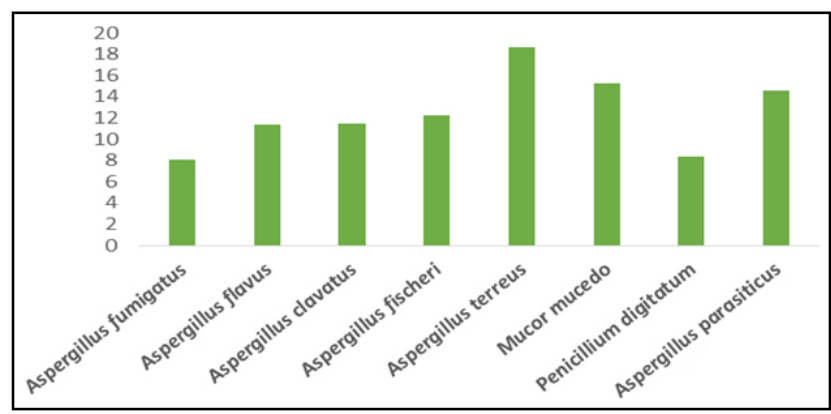

and wrongful human handling [27]. For this, it therefore calls for great attention to handle fish in more hygienic ways to keep up to microbiological standard of the use of fishing equipment which often serve as a route of contamination of frozen fish and storage environment. Conclusion by Brooks et al. [28], was that contaminated food is one of infection sources in man. Foodstuffs safety are generally ensured by a preventive approach, which could be achieved by implementation of good hygiene practice and the use of the principles of hazard analysis and critical control point HACCP). Popovic et al. [12], have therefore reported that microbiological criteria are useful in the procedure of validation and HACCP verification procedures; and other control measures relating to good hygiene practice. Most of the isolated microbes might not be directly associated with the fish but it is cleared that microorganisms localize frozen fish and it is a message that fish must be properly processed either by cooking, frying or drying for save consumption.

\section{Conclusions}

Both pathogenic and spoilage microbes were isolated from the frozen fish and it signals that microorganisms in frozen fish can serve as health hazard to consumers if not properly processed before consumption and labour loss to sellers if adequate preservation of fish is not relatively considered as important factor . Though the microbial load recorded from the fishes is minimal and can be accepted but the pathogenic microorganisms isolated emphasized that frozen fish can serve as possible vehicle for human infection. Every home in Nigeria consume fish on daily bases in their diet. The consumed fish are either in inform of dried, boiled or fried and till date there is no literature or data on disease outbreak as result of consuming frozen or processed fishes. However, this research evaluated that infection with microbial pathogens could be possible from frozen fish and also parts of the results obtained could serve as useful reference in future.

\section{References}

[1]. Håstein T, Hjeltnes B, Lillehaug A, Utne Skåre J, Berntssen M, Lundebye AK. Food safety hazards that occur during the production stage: challenges for fish farming and the fishing industry. Rev Sci Tech. 2006 Aug; 25(2): 607-25. PMID: 17094701

[2]. Center for Food Safety and Applied Nutrition (CFSAN). 2001.

[3]. Adebayo-Tayo BC, Odu NN, Anyamele LM, Igwiloh NJ, Okonko IO. Microbial quality of frozen fish sold in Uyo Metropolis. Nature and Science. 2012; 10(3): 71-7.

[4]. Kvenberg JE. Nonindigenous bacterial pathogens. In Microbiology of Marine Food Products. Springer, Boston, MA. 1991; 267-284.

[5]. Frazier WC, Westhoff DC. Food Microbiology. (4th Edtn). McGraw- Hill Book Company, Singapore. 1988; 56.

[6]. Food and Agriculture Organization (FAO). Food Safety Regulations Applied to Fish by the Major Importing Countries. Rome. 1989; 107.
[7]. Obi SKC, Krakowiaka A. Theory and Practice of Food Microbiology (Unpublished manual), 1983.

[8]. Cheesbrough M. District laboratory practice in tropical countries, part 2. Cambridge university press. 2005; 40-56.

[9]. Bergey DH, Holt G. Bergey's manual of Determinative Bacteriology, 9th edn Williams and Wilkins. Baltimore, MD. 1994.

[10]. Barnett JA, Payne RW, Yarrow D. Yeasts: characteristics and identification. Cambridge University Press, New York, 1983.

[11]. International Commission of Microbiological Specification for Food (ICMSF). Microorganisms in Food 2. Sampling for Microbiological Analysis: Principles and Specific Applications, University of Toronto Press, Toronto, Canada. 1986.

[12]. Topić Popović N, Benussi Skukan A, Džidara P, Čož-Rakovac R, StrunjakPerović I, Kozačinski L, et al. Microbiological quality of marketed fresh and frozen seafood caught off the Adriatic coast of Croatia.

[13]. Sanjee SA, Karim M. Microbiological quality assessment of frozen fish and fish processing materials from Bangladesh. International journal of food science. 2016 Feb 25; 2016.

[14]. Saleem MJ, Hannan A, Qaisar TA. Occurrence of Aflatoxins in Maize Seed under Different Conditions. International Journal of Agriculture \& Biology. 2012 Jun 1; 14(3).

[15]. Oranusi SU, Olarewaju SA. Mycoflora and aflatoxin contamination of some foodstuffs. International Journal of Biotechnology and Allied Fields (IJBAF). 2013; 1(1): 9-18.

[16]. Oranusi SU, Braide W, Etinosa-Okankan OJ. Prevalence of geohelminthes on selected fruits and vegetables sold in Owerri, Imo State, Nigeria. African Journal of Food Science and Technology. 2013; 4(2): 35-43.

[17]. Shimoda K, Maejima K, Urano T. Drug resistance in Streptococcus faecalis, Streptococcus faecium and Staphylococcus epidermidis isolated from laboratory animals. Jikken Dobutsu. 1984 Jul; 33(3): 351-5. PMID: 6437850.

[18]. Wagner Jr AB. Bacterial Food Poisoning. Leaflet/Texas Agricultural Extension Service; no. 1540. 1989

[19]. Roche SM, Gracieux P, Albert I, Gouali M, Jacquet C, Martin PMV, et al. Infection and Immunity. 2003; 71: 3429-3436.

[20]. Harrington SE. The health insurance reform debate. Journal of Risk and Insurance. $2010 \mathrm{Mar}$; 77(1): 5-38.

[21]. Berrang ME, Frank JF, Meinersmann RJ. Contamination of raw poultry meat by airborne Listeria originating from a floor drain. Journal of Applied Poultry Research. 2013 Mar 1; 22(1): 132-6.

[22]. Okonko IO, Adejoye OD, Ogun AA, Ogunjobi AA, Nkang AO, AdebayoTayo BC. Hazards analysis critical control points (HACCP) and microbiology qualities of sea-foods as affected by handler's hygience in Ibadan and Lagos, Nigeria. African Journal of Food Science (ACFS). 2009; 3(2): 35-50.

[23]. Chukwuka KS, Okonko IO, Adekunle AA. Microbial ecology of organisms causing pawpaw (Carica papaya L.) fruit decay in Oyo State, Nigeria. Am. Eurasian J. Toxicol. Sci. 2010; 2(1): 43-50.

[24]. Akinmusire OO. Fungal species associated with the spoilage of some edible fruits in Maiduguri Northern Eastern Nigeria. Advances in Environmental Biology. 2011 Jan 1; 5(1): 157-61.

[25]. Hassanien FS, Shaltout FA, ELbaba AH, Adel NM. Microbiological evaluation of some frozen and salted fish products in Egyptian markets. Benha Veterinary Medical Journal. 2017 Dec 1; 33(2): 317-28.

[26]. Murad HO, Khidhir ZK, Arif ED. Assessment of the microbial quality of imported frozen fish fillets in Sulaimani markets. Al-Anbar J. Vet. Sci. 2013; 6(1): 24-31

[27]. Thatcher FS, Clark DS. Micro-organisms in foods: their significance and methods of enumeration. Micro-organisms in foods: their significance and methods of enumeration. 1968.

[28]. Horton N. Jawetz, Melnick and Adelberg's Medical Microbiology-[Book Review]. Australian Journal of Medical Science. 2004 Feb; 25(1): 41. 